\title{
THE APPLICATION OF CONSTITUTIONAL STANDARDS OF PROTECTION TO PROBATION*
}

\author{
HEINZ R. HiNK †
}

I

N SEARCHING for legal standards for the protection of persons convicted of a criminal offense three procedural stages following conviction have to be considered: sentence, probation, and parole.1 Until recently students of public law, political scientists and lawyers alike, have neglected these aspects of criminal procedure. Responsibility for the conceptual exploration of these areas has been assumed by criminologists and persons interested in penal reform. The traditional concern of the public law profession for the protection of individual rights has expressed itself in vigorous attention to the constitutional safeguards of a person accused of a crime. Committed to the Bill of Rights, the due process and equal protection clauses of the fourteenth amendment, and corresponding provisions in state constitutions, students of public law have closely followed-and at times have stimulatedjudicial interpretation of such constitutional rights as freedom from arbitrary arrest, from unlawful search and seizure, from excessive bail; the right to proper notice and to a fair and impartial trial, to trial by jury, to the assistance of counsel;2 and the constitutional protection against ex post facto laws, cruel and unusual punishment, and double jeopardy.

* This article is based on ideas originally set forth in a paper delivered at the annual meeting of the Western Political Science Association, Berkeley, California, April 1960. The author wishes to express his gratitude to his co-panelist, Professor Ned V. Joy, of San Diego State College, for a stimulating interchange of ideas.

† Associate Professor of Political Science, Arizona State University. LL.B., 1948, University of Berlin, Germany; M.A., 1952, Ph.D., 1957, University of Washington (Seattle).

i Sentence means the pronouncement by the court of the penalty to be imposed on the defendant. Probation is the release of a convicted defendant by the trial court, ordinarily without imprisonment, but subject to certain conditions imposed by the court. Parole is release granted to the prisoner by an administrative act after he has served a portion of his sentence. See Orfield, Criminai Procedure From Arrest to Appeal 535 (1947); WoOd \& WAITE, CRIME AND ITS TREATMENT 630 (1941); Weber, Explorations in the Similarities, Differences and Conflicts Between Probation, Parole and Institutions, 48 J. CRIM. L., C. \& P.S. 580 (1958).

2 The continuing concern of the Supreme Court of the United States with due process again was evidenced in one of the first cases decided this Term. In Hamilton v. Alabama, 368 U.S. 52 (1961), the Court held that arraignment was so critical a stage of Alabama criminal procedure that the defendant was entitled to counsel at arraignment. The defendant's conviction was reversed even though no prejudice was shown to have resulted to him from the denial of counsel. 
But public lawyers have given little attention to the legal protection of an individual once he has been convicted of the crime for which the law secured him every possible procedural safeguard while he stood accused. Several reasons may be offered in explanation of this failure, but perhaps the most important one may be found in the absence of specific constitutional provisions for the protection of procedural rights in a criminal case once the defendant has exhausted all appellate remedies. With the exception of prohibiting cruel and unusual punishment, the United States Constitution and the constitutions of most states do not contain specific provisions designed to safeguard the rights of a convicted defendant whose case has become res judicata.

The primary concern of the public law profession is with constitutional controversies, and the legal forum for the decision of these issues traditionally has been the United States Supreme Court. Consequently, lawyers and political scientists have approached public law from an operational vantage point in intellectual proximity to the Supreme Court. Concern with lower courts has been mainly to the extent to which their decisions have been the basis of Supreme Court review. The important legal issues involved in parole and probation show the limitations attached to this position. The wide range of trial court discretion in matters of sentence, probation, and parole has found appellate courts highly unwilling to establish definite criteria for the use of trial judges. The highest tribunals in most states and the federal Supreme Court have been reluctant to discuss these aspects of criminal procedure in constitutional language. But from this it does not follow that there are no constitutional problems connected with probation. It merely requires that students of public law should leave their traditional vantage point and follow more closely the jurisprudence of lower state and federal tribunals in areas of constitutional significance. Public lawyers may find that the work of these courts offers research opportunities that in the past have largely been ignored.

\section{I}

For two reasons, probation should receive attention in terms of constitutional standards of protection. First, for the same reason by which the law insists on the rigorous observance of constitutional standards in the treatment of a person accused of a crime, it should be concerned with the adequate procedural protection of the same individual once he stands properly convicted. A recent decision of the Michigan Supreme Court clearly defines this obligation: "We reject, instanter, any thought that the defendant, because a convicted criminal, stands before us with any degree of vulnerability, that he is shorn of any of his constitutional rights. These guarantees, in truth, meet their real challenge when sought to be employed by the wicked. The upright and the righteous need them not." 3 One may disagree with the author of the opinion that "the upright and the righteous" do not need the protection of

3 People v. Becker, 349 Mich. 476, 487, 84 N.W.2d 833, 839 (1957). 
constitutional guarantees, but in any case the point is well taken that the strength of a constitutional system lies in the protection it affords those who have trespassed.

In the problem at hand, a second consideration reinforces and illustrates the validity of the first. From the point of view of the substantive protection of an individual, the traditional distinction between the rights of the accused and the rights of the convicted defendant is unrealistic and injures the professed objectives of our modern system of criminal justice. Under the influence of the classical school of criminology the nineteenth century has seen the statutory enactment of more humane and reasonable standards of punishment. We have made the punishment fit the crime. But we have done more than that. Following the positivist school in their belief that deterrence and retribution are not enough, but that reform and social rehabilitation should play a vital part among the functions of criminal law, we have also made punishment suitable to the defendant. Flexibility in the type as well as in the amount of punishment is the motto of modern criminology; the indeterminate sentence, probation, and parole are its products.

It is not suggested here to argue against the usefulness or desirability of these advances over the chain gang and penal colonies. It is suggested, however, that the advantages of a flexible system of punishment allocation may be lost, unless flexibility is brought into line with procedural standards cognizant of the fact that the defendant is as much interested in the actual punishment he will receive as he is in the safeguards protecting his innocence. Criminal procedure should clearly realize that the defendant's interest is not limited to the right of having every possible opportunity of contesting the charge brought against him. The real interest of a guilty defendant extends to the nature of the punishment society inflicts upon him. One of the purposes of flexibility in punishment is to permit the rehabilitation of the criminal, especially the first offender. For this we pay a heavy price, in that we have lost in modern criminal law the certainty characteristic of the common law. But we also will endanger the success of flexibility and lose both certainty and social rehabilitation if we withhold from the convicted offender that degree of predictability which only adequate standards of procedural protection reasonably can secure.

Against this it may be argued that an insistence on rigid forms of procedural protection could defeat the whole probation program. Judges may be discouraged from granting probation if the probation process should be subjected to highly technical rules. There is much validity to such an argument, and this paper is not intended to advocate that all standards applied at criminal trials be extended to probation. The real question is to what extent procedures can be employed that will permit probationers a greater degree of safeguards without defeating the purposes of the probation system. Similar questions 
could be asked, of course, with regard to the indeterminate sentence and parole, though the following remarks will be limited to probation.

The problem of probation standards arises mainly in two areas: (1) the conditions which may be imposed upon granting probation; and (2) the procedure which may be employed in revoking or modifying a probation order. The first area raises questions of procedural and substantive protection, the second one is primarily concerned with procedural standards.

II

The power of the trial court to grant probation is inherent or statutory. 4 In neither case does the grant of probation constitute an infringement on the executive power to pardon. 5 The granting of probation is entirely within the discretion of the trial court. It is "an act of grace and clemency to be granted in a proper case, and a person is not entitled to it as a matter of right."6 Probation is the power of the sentencing court, "when satisfied that the ends of justice and the best interests of the public as well as the defendant will be served thereby," 7 to release the defendant.

The importance of probation as a modern corrective device can be seen from its increasing utilization by the courts. For most states up-to-date statistics are difficult to obtain and, in fact, in many states only very fragmentary records are kept of the state-wide use of probation. However, the following figures should suffice to prove the point. In California in 1955, 6,734 persons convicted, or 44.2 per cent of those sentenced, were placed on probation. For 1956 the corresponding figures are 7,348 or 43.5 per cent; and for 1957, 9,014 or 45.9 per cent. 8 In federal courts, during the year ending June 30, 1959, a total of 10,726 (39.7 per cent) adult offenders were given suspended sentences and placed on probation, of a total of 27,033 criminal defendants convicted and sentenced. During the same period 653 (48.1 per cent) of a total of 1,356

4 The first probation statute was enacted in Massachusetts in 1878. MAss. Acrs ch. 198 (1878). For the history of probation and the earlier common law expedients of benefit of clergy, judicial reprieve and recognizance, see U.N. Dep'T OF Soctal AfFaIRS, Probation AND RELATED MATTERS 15-50 (1951). For a discussion of the inherent or statutory nature of probation see Justice DeP'T ATT'Y GEN SURVEY OF RELEASE PROCEDURES, vol. II (1939); 15 Am. Jur. Criminal Law $\$ 494$ (1938). PuttKammer, Administration of Criminal Law 218 (1953); ORFIEID, op. cit. supra note 1, at 582; WoOD \& WAITE, op. cit. supra note 1, at 631. For a discussion of specific state probation statutes see Aultman, Probation and Parole Act of 1956, 29 Miss. L. J. 76 (1957); Taylor, Probation and the Suspended Sentence in Texas, 34 TeXas L. Rev. 104 (1955).

5 Riggs v. United States, 14 F.2d 5 (4th Cir. 1926).

6 Ex parte Trombley, 31 Cal.2d 801, 811, 193 P.2d 734, 741 (1948). Accord, Burns v. United States, 287 U.S. 216, 220 (1932): "Probation is thus conferred as a privilege and cannot be demanded as a right."

718 U.S.C. $\$ 3651$ (1958). Release is ordinarily accomplished without imprisonment. But see CAL. PEN. CODE $\S 1203$ (1958), which permits as a condition of probation that the probationer be required to serve a part of his sentence.

8 Cal. Bureau of Criminal Statistics, Crime in California 80 (1957). 
juvenile defendants convicted and sentenced were granted suspended sentence and probation. 9 During the year ending June 30, 1960, 10,391 (38.9 per cent) adult offenders of a total of 26,728 sentenced and convicted in federal courts were placed on probation, and 690 (48.3 per cent) of a total of 1,428 convicted and sentenced juvenile offenders were granted the same privilege.10 In the Superior Court of Maricopa County, Arizona, 538 of a total of 1,058 adults convicted and sentenced between July 1, 1960 and June 30, 1961 remained free on probation, or slightly more than 50 per cent.11 These statistics speak for themselves. They indicate the need to attend to the legal problems surrounding probation, which so far have received surprisingly little attention. 12

Probation, in the strict sense of the term, requires some degree of supervision by a probation officer, though in some cases the defendant simply may be released from custody with only the restriction that he does not violate the law again while his sentence is suspended. Courts may grant suspension of sentence either by imposing sentence and suspending the execution thereof, or by suspending the imposition of sentence. As long as a probationer fulfills the conditions imposed by the court the result of either method is the same, i.e., the release of the defendant; 13 but in case of revocation of probation the consequences attached to each method may be substantially different.14

Since probation is an act of grace, judges have considerable latitude as to the substantive content of conditions they may wish to impose. Probation statutes usually give the trial judge broad discretion. According to the Federal Probation Act the judge may impose "such terms and conditions as the court

91959 AnN. Rep. Administrative Office of the United States Courts 236-38 (1960).

101960 Ann. Rep. Administrative Office of the United States Courts 304-09 (1961). There are now more than 26,000 persons under the supervision of United States probation officers. Id. at 310-15. In England and Wales, of 116,000 persons found guilty by the courts in $1956,28,000$ were placed on probation (16,000 out of 39,000 young offenders; 12,000 out of 77,000 adult offenders). See REPORT OF THE CAMBRIDGE DEPARTMENT OF CRIMINAL SCIENCE, The Results of Probation xii (1958). Figures for England and Wales from 1948-1955 are also given. Id. at 110.

11 Adult Probation Dep't Ann. Rep. Superior Court of Maricopa County (1960-1961) on file in Adult Probation Department, Maricopa County Courthouse, Phoenix, Arizona.

12 Two recent discussions represent notable exceptions to this lack of attention: Note, Legal Aspects of Probation Revocation, 59 ColuM. L. Rev. 311 (1959); and Comment, Probationer's Right to Appeal; Appellant's Right to Probation, 28 U. CHI. L. REv. 751 (1961).

1315 Am. Jur. Criminal Law \$ 479: "The courts use the phrase 'suspending sentence' as meaning both delay in the giving of sentence and also staying the execution of a sentence imposed." Korematsu v. United States, 319 U.S. 432, 435 (1943): "The difference to the probationer between imposition of sentence followed by probation . . . and suspension of the imposition of sentence ... . is one of trifling degree."

14 The distinction between imposition of sentence followed by probation and suspension of the imposition of sentence also is of no practical significance in the area of probationer's right to appeal. See Comment, Probationer's Right to Appeal; Appellant's Right to Probation, 28 U. CHI. L. REv. 751, 757 (1961). However, the distinction is not always artificial. It can be of considerable significance upon revocation of probation. See Part IV infra. 
deems best."'1s The California Penal Code provides that conditions of probation must be "reasonable."16 To determine the meaning of such legislative language is difficult, though attempts in this direction have been made.17 These attempts have not always been successful. For example, a California District Court of Appeals has found it a reasonable condition of probation that the syphilitic defendant, convicted of statutory rape, submit to a vasectomy. 18 It is difficult to see where such sterilization, though it would prevent the procreation of syphilitic descendants, would suppress a future recurrence of the anti-social urges for which the defendant was convicted. On the whole it appears that the cases interpreting "reasonable" have not added much content to probation standards.

An interesting problem is raised where the court requires the probationer to leave the state and not to return for the period of probation. In a 1930 Prohibition case the Michigan Supreme Court has held such a condition invalid on the grounds that the practice of a state to "dump" its criminals on other states would invite retaliation and was in violation of the fundamental equality of states. The condition was rescinded on the ground that it was against accepted public policy. ${ }^{19}$ A California court, in a case involving a similar condition, refused to rule on the trial court's power by holding that the defendant had indicated her refusal to accept probation. 20

Another group of cases discusses the power of the sentencing judge to make payment of a sum of money by the defendant to a third party a condition of probation. ${ }^{21}$ In this type of case appellate courts may look for a standard of fairness and reasonableness, but on the whole they have refused to review conditions imposed by the trial court in terms of constitutional language. 22

Is 18 U.S.C. § 3651 (1958). Similarly, ARIz. Rev. STAT. ANN. § 13-1657 A(1) (1956): "upon such terms and conditions as the court determines."

16 Car. Pen. Code $\$ 1203.1$ (1958 Supp.).

17 E.g., Redwill v. Superior Court, 43 Ariz. 68, 78, 29 P.2d 475, 479 (1934): "[The] condition ... must be one which has some reasonable bearing upon the prevention of future crime"; Varela v. Merrill, 51 Ariz. 64, 76, 74 P.2d 569, 574(1937): "It would be almost impossible to present a case which would justify this court in finding that the trial court had abused its discretion in regard to whether sentence should be suspended or not."

18 People v. Blankenship, 16 Cal. App. 2d 606, 61 P.2d 352 (1939).

19 People v. Baum, 251 Mich. 187, 231 N.W. 95 (1930).

20 People v. Billingsley, 59 Cal. App. 2d 845, 139 P.2d 362 (1943).

21 E.g., People v. Becker, 349 Mich. 476, 84 N.W.2d 833 (1957); People v. Prell, 299 Ill. App. 130, 19 N.E.2d 637 (1939); State v. Barnett, 110 Vt. 221, 2 A.2d 521 (1939); People v. Good, 287 Mich. 110, 282 N.W. 920 (1938).

22 The one clear use of constitutional language may be found in People v. Becker, 349 Mich. at 486, 84 N.W.2d at 838: "[E]ven where imposition of the restitution requirement is held to be proper under the circumstances of the particular case before the court, it can be imposed only as to loss caused by the very offense for which defendant was tried and convicted. As to the other crimes or offenses there has been no fixing of his liability therefor in a constitutional sense." 
Do not provisions in the federal and in state constitutions offer a possible source of limitations on the substantive content of probation provisions? Three such provisions in the United States Constitution would appear to be applicable: the due process clause in the fifth and in the fourteenth amendments, the prohibition of cruel and unusual punishment in the eighth amendment, and the equal protection clause in the fourteenth amendment.

The case law shows little evidence of the courts' readiness to apply these constitutional limitations to probation cases. The one clear exception is the 1957 Becker case referred to at the beginning of this paper. In that case, the Michigan Supreme Court (emphasizing the legal distinction between restitution and reparation) held that it was a violation of due process to impose as a condition of probation in a hit-and-run conviction the payment of a sum of money by the defendant to the injured witness, inasmuch as the liability of the defendant for the injuries sustained had not been fixed in a constitutional sense. 23

Another possible constitutional approach to protect probationers against harsh probation conditions would be through the eighth amendment. It can well be argued that the condition imposed by the California court, requiring sterilization, constitutes the infliction of cruel and unusual punishment. It is uncertain, of course, to what extent the fourteenth amendment prohibits states from inflicting such punishment in the absence of a specific provision to that effect in the state constitution. ${ }^{24}$ But even in a federal case the argument has not been successful. The Ninth Circuit Court of Appeals has held that "the conditions of probation are not punitive in character and the question of whether or not the terms are cruel and unusual and thus violative of the Constitution of the United States does not arise for the reason that the Constitution applies only to punishment. These conditions of probation are intended to be an amelioration of the punishment prescribed by law for the given offense." 25 If the court admits that probation is intended to substitute a milder form of retribution for the original punishment, how can it follow that probation must not meet at least the same degree of constitutional limitation against cruel and unusual terms? A reviewer rightly remarks that there is in fact no meaningful distinction from the point of view of a convicted defendant between imposition of the condition and imposition of punishment for the crime for which he was convicted. The threat of lengthy imprisonment may virtually force the defendant to accept such a condition. 26

23 lbid.

24 See Note, Legal Aspects of Probation Revocation, 59 Colum. L. REv. 311,319 n.59 (1959). Some state constitutions, however, contain prohibitions against the infliction of cruel and unusual punishment: Mo. CoNST. art. I, $\$ 21$; WIS. CONST. art. I, § 6; UTAH Const. art. $1, \S 9$.

25 Springer v. United States, 148 F.2d 411, 415 (9th Cir. 1945).

${ }^{26}$ Note, Legal Aspects of Probation Revocation, 59 CoLum. L. Rev. 311, 319 (1959). 
This argument could be extended even further. One may ask, in view of the large number of first offenders placed on probation, whether fulfillment of the conditions contained in the probation order does not in reality become the punishment to which the convicted defendant is sentenced? Is the reasoning of the Ninth Circuit Court of Appeals really valid? The Supreme Court has pointed out that sterilization "involves one of the basic civil rights of man. Marriage and procreation are fundamental to the very existence and survival of the race. The power to sterilize, if exercised, may have subtle, far-reaching and devastating effects.... There is no redemption for the individual whom the law touches. Any experiment which the State conducts is to his irreparable injury. $\mathrm{He}$ is forever deprived of a basic liberty." $27 \mathrm{Can}$ it be maintained that a defendant placed on probation has less of a right to be protected against sterilization than the courts might be willing to grant to a defendant facing punishment? In Trop v. Dulles, Mr. Chief Justice Warren has interpreted the eighth amendment very broadly: "The Amendment must draw its meaning from the evolving standards of decency that mark the progress of a maturing society." 28 Perhaps this language indicates that "cruel and unusual punishment" has no intelligible outline at all. But if it does have such an outline, "the progress of a maturing society"-which has substituted rehabilitation for imprisonment -requires that the conditions of probation should not be permitted to be any more cruel and unusual than the terms of punishment.

Finally, it may be asked whether the equal protection clause of the fourteenth amendment does not place constitutional limits on probation conditions? The "equal protection" argument is forcefully advanced in a recent Comment on "Probationer's Right to Appeal; Appellant's Right to Probation" in this Law Review. 29 The author of that Comment argues convincingly that it is against the equal protection clause to require a defendant to make a choice between probation and appeal. It is irrelevant, in his opinion, that probationers are not incarcerated. They are neither more nor less worthy of protection than prisoners because the court has adjudged them capable of rehabilitation. "The indisputable fact is that to be placed on probation is to be punished. Defendants ought not to be discriminated against on the ground that they have received probation rather than incarceration any more than should defendants who have been fined rather than incarcerated." 30 This argument applies with equal force to conditions of probation. In the Skinner case the state discriminated between thieves (subject to sterilization) and em-

27 Skinner v. Oklahoma, 316 U.S. 535, 541 (1942). The Oklahoma sterilization statute was declared unconstitutional under the equal protection clause; but the Court expressly reserved the question of whether the statute violated the cruel and unusual punishment prohibition. Id. at 538.

28356 U.S. 86, 101 (1957).

2928 U. ChI. L. Rev. 751, 760-61 (1961).

$30 \mathrm{Id}$. at 761 . 
bezzlers (not so subject); in probation cases the discrimination is between defendants amenable to rehabilitation (probationers) and defendants not so amenable (prisoners).

\section{III}

Despite the broad discretion of the trial court to grant or to withhold probation and to impose conditions, it is a universal rule that probation, once granted, cannot be revoked except for violation of a condition. ${ }^{31}$ But there is a good deal of diversity as to the procedure accorded probationers in case of revocation with regard to the right to receive notice, have a hearing, inspect and present evidence and cross-examine, and be assisted by counsel.

The most crucial and elementary problem of procedure is that of allowing the accused a hearing before revoking his probation. Statutory requirements vary. The Federal Probation Act and the probation statutes of a number of states require that a probationer accused of violating the conditions of his release should be "taken before the court," 32 or must be given an "opportunity to be heard," 33 a "summary hearing," 34 an "oportunity to be fully heard," 35 or simply that he should be given a "hearing." 36 Other statutes specifically state that a hearing is not required. ${ }^{37} \mathrm{~A}$ third group of statutes, including the Arizona and the California probation laws, are construed as not requiring a hearing, ${ }^{38}$ though the California courts have granted probationers a hearing regularly as a matter of discretion. 39

31 Compare Note, Legal Aspects of Probation Revocation, 59 CoLum. L. REV. 311, 314 (1959), with cases cited note 24 supra.

32 E.g., 18 U.S.C. § 3653 (1958); MIss. CODE ANN. § 4004-25 (1956) ("brought before the court"); WASh. REv. CODE $\S 9: 95.220$ (1951) ("brought before the court"); Wis. STAT. $\$ 57.01$ (1959) ("brought before the court").

33 E.g., N.Y. Code Crim. Proc. \$ 935; N.Y.C. Crim. CTs. Act § 154.

34 E.g., IDAHo Code ANN. § 20-222 (1949); N.H. Rev. STAT. ANN. § 504.4 (1955); N.J. Stat. ANN. \$2A:168-4 (1953); Ore. Rev. Stat. \$137.550 (1953); W. VA. CodE ANN. $\S 6291(17)(1961)$.

35 E.g., Fla. Stat. ANN. $\$ 948.06$ (1944); GA. Code ANN. § 27-2713 (Supp. 1958).

36 E.g., Ala. CODE tit. 42, § 24 (1961); Colo. Rev. Stat. ANN. \$ 39-16-9 (1953); IND. ANN. Stat. \$ 9-2211 (1956); LA. Rev. Stat. \$15:533 (1950); N.C. Gen. Stat. \$ 15-200 (Supp. 1959); Tenn. Code AnN. $\$ 40-2907$ (1955); TeX. Code Crim. Proc. art. 781 b(5) (1950).

37 E.g., DEL. CODE ANN. tit. 11, §4321 (1953) ("without any further proceeding"); N.Y.C. DOM. REL. CT. ACT $\$ 135$ ("without a further hearing").

38 ARIz. REv. STAT. \$ 13-1657 (1956) ("without warrant or other process"). See Ex parte Johnson, 53 Ariz. 161, 164, 87 P.2d 107, 108 (1939). CAL. PEN. CODE $§ 1203.2$ : "At any time during the probationary period ... the court may in its discretion issue a warrant for the rearrest of any such person and may thereupon revoke and terminate such probation, if the interests of justice so require, and if the court in its judgment, shall have reason to believe from the report of the probation officer, or otherwise, that the person so placed upon probation is violating any of the conditions of his probation, or engaging in criminal practices, or has become abandoned to improper associates or a vicious life." See In re Davis, 37 Cal.2d 872, 874-5, 236 P.2d 579, 581 (1951): in the absence of statutory procedural regulation, "the administration of justice is better served by permitting ex parte revocation of 
In a number of cases probationers have asserted that the lack of certain procedural safeguards, such as the right to an adequate hearing, is violative of the constitutional requirement of due process of law. The courts are divided on this issue. Most state supreme courts refuse to find a violation of due process on the ground that probation is a privilege not protected by the Constitution. A typical example of this type of judicial reasoning is presented by the Michigan Supreme Court:

Respondent has not been deprived of his liberty without due process of law. When he pleaded guilty to the information filed against him, he might have been sentenced at once. It is only by the mercy of the law that he was given probation. If by the violation of the terms of his probation he is called before the court for sentence for the crime of which he had freely pleaded guilty, it cannot be said that he is deprived of his liberty without due process of law. 40

The United States Supreme Court, in one of the rare cases reaching that tribunal on questions of probation procedure, has held that "while probation is a matter of grace, the probationer is entitled to fair treatment and is not to be made the victim of whim or caprice." 41 Some state courts have gone further and have admitted the probationer's right to due process in the constitutional sense. The New Mexico Supreme Court has held that: "Upon principle it would seem that due process of law would require notice and opportunity to be heard...."42 The same opinion was expressed by the Utah Supreme Court in a decision which is also worth noting for its reasoning:

The purpose of the law permitting the suspension of sentence is clearly reformatory. If those who are to be reformed cannot implicitly rely upon promises or orders contained in the suspension of sentence, then we may well expect the law to fail in its purpose. Reformation can certainly best be accomplished by fair, consistent, and straightforward treatment of the person sought to be reformed. It would therefore seem, both upon authority and principle that when a sentence is suspended during good behavior, without reservations, the person whose sentence is thus suspended

probation than by absolutely requiring notice and hearing." Accord, In re Levi, 39 Cal.2d 41,244 P.2d 403 (1952), where the court held that there is no constitutional or statutory right to a hearing preceding revocation of probation. If such a hearing is granted, it is not subject to the rules governing criminal trials. In People v. McClean, 130 Cal. App. 2d 439, 279 P.2d 87 (1955), it was held that revocation solely on the basis of the report of a probation officer was valid.

39 E.g., Wadler v. Justice Court, 144 Cal. App. 2d 739, 301 P.2d 907 (1956).

40 People v. Dudley, 173 Mich. 389, 397, 138 N.W. 1044, 1047 (1912); Accord, Varela v. Merrill, 51 Ariz. 64, 70, 74 P.2d 569, 572 (1937).

41 Burns v. United States, 287 U.S. 216, 223 (1932). For a discussion of the Burns case see Comment, Probation-Progress Through Legislation, 3 WAYNE L. REV. 125, 131-32 (1957).

42 Ex parte Lucero, 23 N.M. 433, 438, 168 Pac. 713, 715 (1917); Accord, State v. O'Neal, 147 Wash. 169, 172, 265 Pac. 175, 176 (1928). 
has a vested right to rely thereon so long as such condition is complied with. The right to personal liberty is one of the most sacred and valuable rights of a citizen, and should not be regarded lightly. The right to personal liberty may be as valuable to one convicted of crime as to one not so convicted, and so long as one complies with the conditions upon which such right is assured by judicial declaration, he may not be deprived of the same. Such right may not be alternatively granted and denied without just cause. 43

Professor Wechsler recently has argued that the Bill of Rights "leave[s] room for adaptation and adjustment if and when competing values, also having constitutional dimension, enter on the scene." 44 It is suggested that certain aspects of probation have this "constitutional dimension." It constitutes a minimum requirement of fairness - in the sense in which the Supreme Court has applied this standard to pre-trial and trial procedure in order to satisfy the requirements of due process-to allow a probationer accused of probation violation to be heard before revoking the order granting him liberty. If, for instance, the Supreme Court of the United States considers arraignment so critical a stage of criminal procedure that denial of counsel at arraignment must result in reversal of a defendant's conviction, 45 is it not reasonable to argue that the right to counsel and the right to a hearing also are critical and are as worthy of constitutional protection in a revocation of probation proceeding?

The discretionary character of the grant of probation should not deprive its recipient of the standards of procedural protection necessary for a fair determination of his conduct. One has to agree with the conclusions reached in a Note on "Legal Aspects of Probation Revocation" in the Columbia Law Review that recent Supreme Court decisions in the area of public employment 46 and in a case involving admission to the bar 47 "cast increasing doubt on the proposition that an interest is unprotected by the due process clause merely because it was granted as a matter of grace or discretion." 48 Though he found no case discussing this line of reasoning, the author of the Note further suggests that probationers may also "claim a constitutional right to procedural safeguards under the equal protection clause by contending that

43 State v. Zolantakis, 70 Utah 296, 303, 259 Pac. 1044, 1046 (1927).

44 Wechsler, Toward Neutral Principles of Constitutional Law, 73 HARv. L. REv. 1, 19 (1959).

45 Hamilton v. Alabama, 368 U.S. 52 (1961). See note 2 supra.

46 Slochower v. Board of Educ., 350 U.S. 551 (1956); Wieman v. Updegraff, 344 U.S. 183 (1952).

47 Schware v. Board of Bar Examiners, 353 U.S. 232 (1957).

4859 ColUm. L. Rev. 311, 325 (1959). Weihofen, Revoking Probation, Parole or Pardon Without a Hearing, 32 J. CRIM. L. \& C. 531 (1942), favors a hearing in all these cases as a constitutional right as well as a matter of good practice. But on parole see White, Some Legal Aspects of Parole, 32 J. CRIM. L \& C. 600 (1942). 
the difference between factual determinations in a revocation proceeding and those in a trial ... does not reasonably justify the difference between the procedures utilized in each." 49

In the opinion of the present writer the increased use of probation as a modern substitute for traditional forms of legal punishment calls for an extension of constitutional standards to some aspects of probation procedure. The report of a probation officer by itself should never be sufficient cause to revoke a probation order. The accused should always be granted a hearing and have an opportunity to present his side of the case. Explained by the defendant, the alleged probation infraction may appear in an entirely different light. The American Law Institute has found the question of a hearing to be "an area where dangers of abuse are real and the normal procedural protection proper. That a defendant has no right to the suspension or probation does not justify the alteration of his status by methods that must seem and sometimes be unfair." 50 Accordingly, the Model Penal Code, Section 301.4 provides: "The Court shall not revoke a suspension of probation or increase the requirements imposed thereby on the defendant except after a hearing upon written notice to the defendant of the grounds on which such action is proposed. The defendant shall have the right to hear and controvert the evidence against him, to offer evidence in his defense and to be represented by counsel." 51

\section{IV}

Finally, it may be asked, what happens when a probation order is revoked? Here, statutes permitting the judge to suspend imposition of sentence normally empower the court to pronounce the sentence which could originally have been imposed.52 Probation statutes permitting the trial court to suspend the execution of sentence provide in case of revocation either that the original sentence shall become effective, 53 or that the court may impose lesser sentence, 54 or that the court may now impose the punishment which could originally have been imposed. 55

Where statutes permitting the court to suspend the execution of sentence provide that the judge upon revocation of probation may impose the punish-

4959 Colum. L. Rev. at 326.

50 Model Penal Code $\S 301.4$, comment (Tent. Drafts Nos. 2, $1954 \&$ 4, 1955).

st Ibid.

52 E.g., Ariz. Rev. Stat. ANn. § 13-1657 (1956); Colo. Rev. Stat. AnN. § 39-16-9 (1953); KY. REV. STAT. ANN. § 439.050 (1955).

53 E.g., Ariz. Rev. Stat. ANN. \$ 13-1657 (1956); Cal. Pen. Code § 1203.2; Wash. Rev. CODE $\$ 9: 95.220$ (1951).

54 E.g., 18 U.S.C. 3653 (1958); ConN. Gen. Stat. Rev. § 54-114 (1958).

ss E.g., Colo. Rev. Stat. ANN. § 39-16-9 (1953); Ind. ANn. Stat. § 9-2211 (1956); N.Y. Pen. Code $\$ 2188$; N.Y. Code Crim. Proc. $\$ \S 470(a)$, 483(4). See also the Federal Probation Act of 1925 , ch. $521, \S 725,43$ Stat. 1260 . 
ment which could originally have been imposed for the offense committed, the distinction between suspension of the imposition of sentence and suspension of the execution of sentence is artificial. In either case, the defendant whose probation has been revoked may receive the maximum penalty prescribed by law for the offense of which he was convicted. But in jurisdictions with statutes which provide that in case of the revocation of a probation order suspending the execution of sentence the original sentence shall become effective, or that a lesser sentence may be imposed, the distinction between suspension of the imposition of sentence and suspension of the execution of sentence becomes a matter of practical significance. In such jurisdictions probationers under suspended imposition of sentence face the maximum penalty if their probation is revoked; while defendants on probation under suspended execution of sentence are confronted with only the punishment to which they had been originally sentenced.

The authority to increase a suspended sentence upon revocation and the practice of suspending the imposition of sentence until the time of revocation raise basic questions inherent in the whole probation process. Admittedly, probation is a privilege which in most jurisdictions the defendant may refuse if he prefers the punishment. But, where the court suspends the imposition of sentence, does the defendant know his punishment?56 Does he really have a choice? Faced with the possible threat of a long, indeterminate sentence, is the defendant not actually forced into accepting probation and all its conditions? Suspension of imposition of sentence results in great uncertainty. Is such uncertainty necessary for the orderly administration of a successful probation system? Could not trial courts make the alternative to probation more specific without jeopardizing the objectives of probation? A person accused of crime has the right to have a specific charge brought against him. Should not a person found guilty and convicted, but also found deserving of probation, have the opportunity of knowing the alternative to his refusal or violation of probation? Would not such knowledge further the rehabilitation of an offender by making him more willing to fulfill the conditions of the court's probation order?

Another consideration enters into this matter. The trial judge, in granting probation, cannot from a realistic point of view rely on future performance alone. He must also, perhaps primarily, consider the defendant's past character, history and record. Probation is granted on the basis of what the judge knows at the time of sentencing. If later the grant of probation has to be rescinded, the penalty for the original offense still ought to be determined by the circumstances known at the time of sentence. It should not be aggravated by the fact that the accused later violates his probation, a matter for which he had no proper trial. Probation should not become a test of how deserving

36 For examples of the wide range between possible minimum and maximum sentence see WOOD \& WAITE, op. cit. supra note 1, at 436-37. 
the defendant was of punishment for the original crime. The fact that only undeserving probationers, those who have broken conditions of probation, are affected by the present practice of increasing sentence does not matter. Probation is not intended to be punitive in character. Suspension of sentence bears inherent dangers to proper procedural conduct. It would be desirable if the courts would discontinue their practice. 57

The same argument may be used against statutes permitting the court to set aside the original sentence and to impose the punishment which could originally have been imposed. It is doubtful that the courts will find such procedure in violation of the double jeopardy clause of the Constitution: "Under the probation act an increase in sentence is expressly authorized by the statute ... and, consequently, it is potentially a part of the original sentence." 58 Therefore, revocation of a suspended sentence and imposition of a higher penalty "did not constitute double jeopardly under the Fifth Amendment to the Constitution."'s9 But, again, nothing stands in the way of judicial selfrestraint; and it is interesting to note that when the Supreme Court of the United States came to deal with the issue of increasing sentence upon revocation of probation under the Federal Probation Act of 1925, it ruled that the act had not intended to grant this power: " $[\mathrm{H}]$ aving exercised its discretion by sentencing an offender to a definite term of imprisonment in advance of probation, a court may not later upon revocation of probation set aside that sentence and increase the term of imprisonment." 60

To sum up the ideas advanced in this paper: The rigid distinction between the procedural safeguards of a person accused of crime and those of a convicted defendant granted probation is unrealistic. In the interest of the protection of individual rights, which include the rights of persons convicted of

57 But see the arguments of Mr. Justice Frankfurter, in Roberts v. United States, 320 U.S. 264, 273 (1943) (dissenting opinion).

58 Remer v. Regan, 104 F.2d 704, 705 (9th Cir. 1939).

59 Roberts v. United States, 131 F.2d 392, 393 (5th cir. 1943). Reversing on other grounds, the Supreme Court of the United States in this case reserved the question of double jeopardy. See Roberts v. United States, 320 U.S. 264, 265 (1943).

60320 U.S. at 272-73. But see Mr. Justice Frankfurter's dissent, id. at 273-77; and the discussion of the Roberts case in Puttkammer, The Trial Court's Freedom of Discretion in Sentencing After Revocation of Probation, 11 U. CHI. L. REv. 286 (1944). The language of 18 U.S.C. $\$ 3653.4$ (1958) is now changed to bring about conformity with the decision in the Roberts case: "Thereupon the court may revoke the probation and require him to serve the sentence imposed, or any lesser sentence, and, if imposition of sentence was suspended, may impose any sentence which might originally have been imposed." However, the MODEL PENAL CODE $\S 301.3(2)$ (Tent. Draft No. 4, 1955), permits the imposition of the originally possible sentence in suspension-of-execution cases under certain circumstances: "When the Court revokes a suspension or probation, it may impose on the defendant any sentence that might have been imposed originally ... except that the defendant shall not be sentenced to imprisonment unless: (a) he has been convicted of another crime; or (b) his misconduct indicates that his continued liberty involves excessive risk that he will commit another crime; or (c) such disposition is essential to vindicate the authority of the Court or the probation officer and is not unjust to the defendant." 
a criminal offense, probation procedures should be brought into as much conformity with procedural and substantive safeguards as the purpose and the administration of a sound probation program will permit. Though probation is an act of clemency in the discretion of the trial court, a probationer should not be subjected to conditions violative of the intention if not the letter of due process and the equal protection of the law. Before revocation of his probation, or the imposition of more severe probation conditions, the accused should be entitled, as a matter of right, to a hearing before the trial court. Finally, a judicial effort should be made to reconcile the element of flexibility essential to the probation system with safeguards against a later increase in punishment by making the alternative to probation as predictable as possible. 